\title{
The effect of fertiliser treatments on the severity of Fusarium head blight and mycotoxin biosynthesis in winter rye
}

\author{
Bożena Cwalina-Ambroziak ${ }^{1}$, Tomasz P. Kurowski ${ }^{1}$, Agnieszka Waśkiewicz ${ }^{3}$, Piotr Goliński ${ }^{3}$, \\ Arkadiusz Stępieńn ${ }^{2}$ Małgorzata Głosek-Sobieraj ${ }^{1}$, and Adam Perczak ${ }^{3}$ \\ Department of Entomology, Phytopathology and Molecular Diagnostics ${ }^{1}$, Department of Agroecosystems ${ }^{2}$, University \\ of Warmia and Mazury in Olsztyn, Olsztyn, Department of Chemistry, Poznań University of Life Sciences, Poznan'3, \\ Poland
}

[Received in June 2016; Similarity Check in June 2016; Accepted in March 2017]

\begin{abstract}
The fungi of the genus Fusarium cause Fusarium head blight (FHB), a devastating disease that reduces grain yield and quality. They also produce mycotoxins which may pose a serious threat to human and animal health. This study investigated the effects of NPK fertilisation, foliar application of $\mathrm{Cu}, \mathrm{Zn}$, and $\mathrm{Mn}$, applied separately and in combination, and of the Nano-Gro ${ }^{\circledR}$ organic growth stimulator on the occurrence of FHB in cultivar Dańkowskie Diament rye based on the mycological analysis of kernels and on the concentrations of Fusarium mycotoxins in grain. The severity of FHB caused by seven species of the genus Fusarium was influenced by weather conditions in the analysed growing seasons. The applied fertilisation and the Nano-Gro ${ }^{\circledR}$ organic growth stimulator exerted varied effects on FHB development and the biosynthesis of Fusarium mycotoxins (deoxynivalenol, nivalenol, zearalenone and fumonisins) in grain. The greatest reduction in deoxynivalenol and nivalenol concentrations was noted in 2013, and the levels of moniliformin were lower in treated samples than in absolute control (untreated) samples in both years of the study. The severity of FHB positively correlated with the concentrations of zearalenone, deoxynivalenol, nivalenol, and moniliformin in the grain samples. Greater accumulation of ergosterol was noted in the rye grain harvested in 2013 than in 2012, and fertiliser treatment led to higher ergosterol concentrations than did control treatment.
\end{abstract}

KEY WORDS: deoxynivalenol; ergosterol; fertilisation with microelements; FHB; fumonisins; fungi; moniliformin; nivalenol; zearalenone

Fusarium spp., common in all climate zones, can cause many diseases in cereal crops (1-4). These fungi are transmitted through soil and crop residues, compromising plant health as the infection spreads (5). Their pathogens attack plants from the early stages of development $(\mathrm{BBCH}$ 30) to maturity (BBCH 77). Fusarium head blight (FHB) is a dangerous disease of various types of cereals, including rye, around the world. Langevin et al. (6) have demonstrated that rye is less susceptible to infections caused by Fusarium spp. than wheat and triticale, but more susceptible than barley and oats. Fusarium graminearum Schw. (Gibberella zeae Schw. teleomorfa), F. culmorum (WG Smith) Sacc., F. avenaceum (Coda: Fr.) Sacc. (Gibberella avenaceae Cook), F. poae (Pech) Wollenw., F. moniliforme Sheldon ( $=$ F. verticillioides (Sacc.) Nirenberg, G. fujikuroi (Sawada) Wollenw.), and F. tricinctum (Corda) Sacc. (G. tricincta El-Gholl, McRithie, Scoulties, Ridings) are considered to be major pathogens of cereal crops (3, 7-10). Fusarium

Correspondence to: Bożena Cwalina-Ambroziak, Department of Entomology, Phytopathology and Molecular Diagnostics, University of Warmia and Mazury in Olsztyn, 10-719 Olsztyn, Poland;

E-mail:bambr@uwm.edu.pl culmorum and $F$. avenaceum are the most common in Europe, including Poland (2-3, 11). According to Rintelen (12), F. poae and F. tricinctum are more common than $F$. culmorum and $F$. graminearum when dry and cool conditions that prevail during flowering are followed by a wet period at a later stage of development. Champeil et al. (13) found that the severity of FHB in wheat is largely determined by high relative humidity, wind, and rainfall during flowering and harvest.

According to the literature (14-15), these pathogens differ in their responses to fertilisation with nitrate $(\mathrm{N})$, phosphate $(\mathrm{P})$, potassium $(\mathrm{K})$, and microelements. High $\mathrm{N}$ fertilisation levels seem to increase the severity of infections with obligate pathogens but decrease the severity of infections with facultative parasites, including Fusarium spp. (16). Potassium reduces the host plant's susceptibility to infections, but only when applied at optimal rates. Unlike potassium's, phosphate's role in plant resistance to pathogens varies considerably. Microelements such as $\mathrm{Cu}$, $\mathrm{Zn}, \mathrm{Mn}$, and B, in turn, seem to be involved in a plant's physiological and biochemical defence mechanisms against pathogens. Manganese participates in the synthesis of lignin and suberin (17); zinc protects cell membranes against 
oxidative damage (even though rye can tolerate zinc deficiency) (18); copper and boron are involved in cell wall lignifications and the accumulation of phenolic compounds and they enhance the rate of photosynthesis (19-20). An in vitro study has shown that $\mathrm{Zn}, \mathrm{Cu}$, and $\mathrm{Fe}$ inhibit the growth of some fungal species, including Fusarium (21). Another in vitro study (22) demonstrated the inhibitory effects of $\mathrm{ZnSO}_{4}$ and $\mathrm{Zn}\left(\mathrm{ClO}_{4}\right)_{2}$ against $F$. graminearum.

As winter rye (Secale cereale L.) is used for food and feed production, its grain must be of high quality. In kernels infected by Fusarium spp., starch granules and storage proteins are damaged, which reduces flour strength (23). Most importantly, toxigenic Fusarium species (3, 24-25), contaminate grain by producing mycotoxins $(2-3,9,13$, $26)$, which pose a threat to human and animal health (2729). The most common mycotoxins produced by the Fusarium spp. in cereal grains are zearalenone (ZEA), type $\mathrm{B}$ trichothecenes [deoxynivalenol (DON) and nivalenol (NIV)], and fumonisins (FBs) (30-31). Fusarium graminearum and $F$. culmorum are important producers of DON and NIV $(2-3,9,32)$, whereas $F$. verticillioides and $F$. proliferatum are responsible for the biosynthesis of fumonisins (10, 31, 33-34). These compounds exhibit a broad spectrum of toxic effects, including the nephrotoxic, hepatotoxic, teratogenic, carcinogenic, and hyperoestrogenic effects (2, 29, 35-37). Since Fusarium mycotoxins pose a significant risk to human and animal health, many countries have implemented legal regulations specifying the maximum permissible levels of mycotoxins in maize and small-grain cereals (38).

The aim of this study was to evaluate the effects of NPK fertilisation, foliar application of microelements, and the Nano-Gro ${ }^{\circledR}$ growth stimulator on the severity of FHB and mycotoxin concentrations in winter rye kernels. We also determined the levels of ergosterol as a selective indicator of fungal biomass.

\section{MATERIALS AND METHODS}

\section{Plant materials}

Winter rye (Secale cereale L.) cultivar Dańkowskie Diament was grown in 2012 and 2013 in experimental plots. The experiment had a randomised block design with three replications. It was established in Tomaszkowo near Olsztyn $\left(53^{\circ} 72 \mathrm{~N} ; 20^{\circ} 42 \mathrm{E}\right)$ on podzolic soil of a granulometric composition of light loam (complex 4, class IIIb) according to FAO [39]. The plot area for sowing and harvesting was $6.25 \mathrm{~m}^{2}$ and $4.0 \mathrm{~m}^{2}$, respectively. The following analyses were performed with standard methods in the Chemical and Agricultural Station in Olsztyn: soil pH (in 1 molar solution of $\mathrm{KCl})=4.62$, organic carbon content $=7.93 \mathrm{~g} \mathrm{~kg}^{-1}$, total nitrogen content $=0.95 \mathrm{~g} \mathrm{~kg}^{-1}$; plant-available macronutrients: $\mathrm{P}=58.9 \mathrm{mg} \mathrm{kg}^{-1}, \mathrm{~K}=203.4 \mathrm{mg} \mathrm{kg}^{-1}, \mathrm{Mg}=8.1 \mathrm{mg} \mathrm{kg}^{-1}$, $\mathrm{Cu}=2.5 \mathrm{mg} \mathrm{kg}^{-1}, \mathrm{Fe}=1800 \mathrm{mg} \mathrm{kg}^{-1}, \mathrm{Zn}=7.9 \mathrm{mg} \mathrm{kg}^{-1}$, and
$\mathrm{Mn}=189 \mathrm{mg} \mathrm{kg}^{-1}$. The experiment included seven fertilisation treatments: 1). absolute control (without fertilisation); 2) control with NPK (N=90 kg ha-1, $\mathrm{P}_{2} \mathrm{O}_{5}=70 \mathrm{~kg} \mathrm{ha}^{-1}$, and $\mathrm{K}_{2} \mathrm{O}=100 \mathrm{~kg} \mathrm{ha}^{-1}$ ); 3) NPK treatment $2+0.2 \mathrm{~kg} \mathrm{ha}^{-1} \mathrm{Cu}$; 4) NPK treatment $2+0.2 \mathrm{~kg} \mathrm{ha}^{-1} \mathrm{Zn} ; 5$ ) NPK treatment $2+0.2 \mathrm{~kg} \mathrm{ha}^{-1} \mathrm{Mn}$; 6) NPK treatment $2+0.2 \mathrm{~kg} \mathrm{ha}^{-1} \mathrm{Cu}+0.2 \mathrm{~kg} \mathrm{ha}^{-1} \mathrm{Zn}+0.2 \mathrm{kgha}^{-1} \mathrm{Mn}$; 7) NPK treatment $2+\mathrm{Nano}-\mathrm{Gro}^{\circledR}$.

Nitrogen was applied to the soil $\left(54 \mathrm{~kg} \mathrm{ha}^{-1}\right)$ in the form of $46 \%$ granular urea in the tillering stage (BBCH-scale 22-23: 2-3 tillers detectable) and to the leaves (36 kg ha-1) in the form of $10 \%$ urea solution in the stem elongation stage (BBCH-scale 30-31: pseudostem and tillers erect, first node at least $1 \mathrm{~cm}$ above the tillering node) (40). Phosphorus (30.2 $\mathrm{kg} \mathrm{ha}^{-1}$ ) was applied in the form of $46 \%$ triple superphosphate and potassium $\left(83.1 \mathrm{~kg} \mathrm{ha}^{-1}\right)$ in the form of $56 \%$ potash salt before sowing. The microelements $\mathrm{Cu}$, $\mathrm{Zn}$, and $\mathrm{Mn}$ were applied as aqueous solutions separately or in combination in the stem elongation stage (BBCH 3031), as follows: $1 \%$ solution of $\mathrm{CuSO}_{4}, 1 \%$ solution of $\mathrm{ZnSO}_{4}$, and $0.5 \%$ solution of $\mathrm{MnSO}_{4}$.

Nano-Gro ${ }^{\circledR}$ was also applied to the leaves in the stem elongation stage in the form of eight granules dissolved in $300 \mathrm{~L}$ of water per hectare. Nano-Gro ${ }^{\circledR}$ is an organic growth stimulator in the form of oligosaccharide granules containing $\mathrm{Fe}, \mathrm{Co}, \mathrm{Al}, \mathrm{Mg}, \mathrm{Mn}, \mathrm{Ni}$, and $\mathrm{Ag}$ sulphates at a concentration of $10^{-9} \mathrm{~mol}$.

NPK fertilisers and the microelements were applied by machine, and Nano-Gro ${ }^{\circledR}$ by hand.

Winter rye was sown at the rate of $160 \mathrm{~kg} \mathrm{ha}^{-1}$ in 2011 (date of sowing 14 September 2011; date of harvest 31 July 2012) and $172 \mathrm{~kg} \mathrm{ha}^{-1}$ in 2012 (date of sowing 17 September 2012; date of harvest 31 July 2013). The forecrop was winter triticale. Tillage operations were conducted in accordance with the agronomic requirements of rye. In both years, weeds were destroyed with herbicides.

\section{Phytopathological experiment}

For the experiment we created the conditions of natural infection. At the stage of early milk maturity (BBCH 73), the severity of FHB (caused by Fusarium spp.) was estimated on 50 ears per plot. The evaluation was conducted using a five-point scale, where 1 represents up to $5 \%$ of the infested ear area, $26-10 \%, 311-25 \%, 426-50 \%$, and 5 more than $50 \%$ of the infested area. The infestation index (Ii) was expressed as percentage (39).

$$
\mathrm{Ii}=\frac{\sum(\mathrm{axb}) \times 100 \%}{\mathrm{~N} \mathrm{xI}}
$$

where $\Sigma(\mathrm{axb})$ is the sum of the products resulting from the multiplication of the number of plants (a) with points on the five-point scale (b); $\mathrm{N}$ is the total number of plants; and $\mathrm{I}$ is the highest number of points on the scale.

After the harvest, 100 kernels were randomly collected from pooled samples representing each fertilisation 
treatment. The kernels were sterilised in a $1 \%$ solution of sodium hypochlorite $(\mathrm{NaOCl})$ for 3 min and washed three times in sterile water. The fungi were cultured on a potatodextrose-agar medium PDA(Difco ${ }^{\mathrm{TM}}, \mathrm{BD}$, Franklin Lakes, NJ, USA) solidified in Petri dishes and identified under a microscope according to the phytopathological keys and monographs $(41,42)$

\section{Mycotoxin analysis}

\section{Standards and chemical reagents}

Standard-grade moniliformin (MON), zearalenone (ZEA), deoxynivalenol (DON), nivalenol (NIV), fumonisin B1 (FB1) and B2 (FB2), and ergosterol (ERG) were purchased from Sigma-Aldrich (Steinheim, Germany). Sodium dihydrophosphate, potassium hydroxide, sodium hydroxide, potassium chloride, acetic acid, hydrochloric acid, and $o$-phosphoric acid were purchased from POCh (Gliwice, Poland). HPLC-grade organic solvents disodium tetraborate, $n$-pentane, 2-mercaptoethanol, and sodium acetate and all the other chemicals were purchased from Sigma-Aldrich (Steinheim, Germany). Water for the HPLC mobile phase was purified using a Milli-Q system (Millipore, Bedford, MA, USA).

\section{Extraction and purification procedure}

For the analysis we prepared $10 \mathrm{~g}$ of ground and homogenised samples of winter rye kernels (two grain samples per treatment). All mycotoxins (MON, ZEA, DON, NIV, FB1 and FB2) and ERG were extracted and purified according to the detailed procedure described elsewhere (3, 34). The elute was evaporated to dryness at $40^{\circ} \mathrm{C}$ under a stream of nitrogen. Dry residue was stored at $-20{ }^{\circ} \mathrm{C}$ until HPLC analyses.

\section{HPLC analysis}

The chromatographic system consisted of the Waters 2695 high-performance liquid chromatograph (Waters, Milford, MA, USA) with the following detectors:

Waters 2475 Multi $\lambda$ Fluorescence Detector $\left(\lambda_{\text {ex }}=335\right.$ $\left.\mathrm{nm}, \lambda_{\mathrm{em}}=440 \mathrm{~nm}\right)$ with a XBridge column $(3.0 \times 100 \mathrm{~mm})$ for FB1 and FB2 analysis;

Waters 2996 Photodiode Array Detector with a Nova Pak C-18 column $(150 \times 3.9 \mathrm{~mm})$ for $\operatorname{ERG}\left(\lambda_{\max }=282 \mathrm{~nm}\right)$ analysis and a Nova Pak C-18 column $(300 \times 3.9 \mathrm{~mm})$ for $\operatorname{DON}, \operatorname{NIV}\left(\lambda_{\max }=224 \mathrm{~nm}\right)$ and $\operatorname{MON}\left(\lambda_{\max }=229 \mathrm{~nm}\right)$ analysis,

Waters 2475 Multi $\lambda$ Fluorescence Detector $\left(\lambda_{\mathrm{ex}}=274\right.$ $\mathrm{nm}, \lambda_{\mathrm{em}}=440 \mathrm{~nm}$ ) and Waters 2996 Photodiode Array Detector with a Nova Pak C-18 column $(150 \times 3.9 \mathrm{~mm})$ for ZEA analysis.

The mycotoxins were quantified by measuring peak areas and retention times using the calibration curve. The limits of detection were as follows: $1 \mathrm{~kg} \mathrm{ha}^{-1}$ for ZEA,
$10 \mathrm{ng} \mathrm{g}^{-1}$ for DON, NIV and MON, and $5 \mathrm{ng} \mathrm{g}^{-1}$ for FB1-2 and $\operatorname{ERG}(3,34)$.

\section{Statistical analysis}

The results were processed statistically STATISTICA ${ }^{\circledR}$ 10.0 (StatSoft Polska, Kraków, Poland) by the analysis of variance (ANOVA). Mean values were compared with Duncan's test ( $p=0.05$ for the field experiment, $p=0.01$ for biochemical analyses). The correlation between FHB severity and mycotoxin concentrations was determined by calculating correlation coefficients (Pearson's r). The correlation analysis included replication data for 2012 and $2013(\mathrm{~N}=28)$

\section{RESULTS AND DISCUSSION}

\section{The severity of FHB in winter rye}

The development of FHB symptoms and the spread of the disease were influenced by weather conditions from the middle of heading to ripening (Table 1). In 2012, weather conditions favoured the development of FHB. From the middle of heading (BBCH 55) to the end of the early dough stage (BBCH 83), rainfall total reached $230.8 \mathrm{~mm}$. It was fairly uniform over these stages, which, combined with moderate temperature.

The most evident symptoms of FHB (Ii about $21 \%$ ) were recorded in the first season of the study (2012) in the $\mathrm{NPK}+\mathrm{Zn}, \mathrm{NPK}+\mathrm{Mn}$, and $\mathrm{NPK}+\mathrm{Nano}-\mathrm{Gro}^{\circledR}$ treatments (Figure 1). Differences in disease severity between the above and other experimental treatments were statistically significant. Weaker symptoms of FHB were noted in plants treated with NPK plus $\mathrm{Cu}$ and NPK plus the three microelements.

In 2013, the growing season was shorter than in 2012. Due to a relatively low temperature $\left(14.7\right.$ and $15.8{ }^{\circ} \mathrm{C}$ at the beginning and middle of May, respectively) and low rainfall (27 $\mathrm{mm}$ total), some growth stages (BBCH 33, 51 and 59) overlapped or ran concurrently. Low precipitation (78.1 mm total) was also recorded from the end of heading (BBCH 59) to the end of the early dough stage (BBCH 83), and rainfall was not distributed evenly (no precipitation in mid June). In May and June, temperatures exceeded the long-term average, which further lowered relative humidity. The result was inhibited development of FHB. The symptoms of infection caused by Fusarium spp. were mild, and Ii did not exceed $3 \%$ in any of the treatments. Similar to season 2012, disease severity was the lowest in plants subjected to foliar fertilisation with microelements, whereas $\mathrm{NPK}+\mathrm{Cu}$ treatment secured healthy plants at harvest.

Weather conditions, humidity and temperature in particular, may affect the contribution of individual Fusarium species to FHB severity (43). Nutrients such as $\mathrm{N}, \mathrm{K}, \mathrm{P}, \mathrm{Mn}, \mathrm{Zn}, \mathrm{B}, \mathrm{Cl}$, and $\mathrm{Si}$, on the other hand, play an important role in controlling this severity $(15,26)$. The form 
Table 1 Rye growth and weather conditions in 2012 and 2013*

\begin{tabular}{|c|c|c|c|c|c|c|c|c|c|}
\hline \multirow{3}{*}{ Month } & \multirow{3}{*}{$\begin{array}{c}10 \\
\text { days }\end{array}$} & \multicolumn{4}{|c|}{2012} & \multicolumn{2}{|l|}{2013} & \multicolumn{2}{|c|}{ 1961-2010 } \\
\hline & & BBCH-scale & Temp. & Rainf. & BBCH-scale & Temp. & Rainf. & $\begin{array}{c}\text { Temp. } \\
\left({ }^{\circ} \mathrm{C}\right)\end{array}$ & $\begin{array}{l}\text { Rain. } \\
\text { (mm) }\end{array}$ \\
\hline & & (growth stages) & $\left({ }^{\circ} \mathrm{C}\right)$ & $(\mathbf{m m})$ & (growth stages) & $\left({ }^{\circ} \mathrm{C}\right)$ & $(\mathbf{m m})$ & $\mathbf{x}$ & $\sum$ \\
\hline
\end{tabular}

\begin{tabular}{|c|c|c|c|c|c|c|c|c|c|}
\hline \multirow{4}{*}{ May } & I & $\begin{array}{l}51 \text { Beginning } \\
\text { of heading: tip } \\
\text { of inflorescence } \\
\text { emerged from sheath, } \\
\text { first spikelet just } \\
\text { visible }(05.05 .12)\end{array}$ & 13.1 & 0.8 & $\begin{array}{l}\text { and tillers erect, first } \\
\text { internode begins } \\
\text { to elongate, top of } \\
\text { inflorescence at least } 1 \\
\mathrm{~cm} \text { above tillering node } \\
\quad(06.05 .13) \\
32 \text { Node } 2 \text { at least } 2 \mathrm{~cm} \\
\text { above node } 1(10.05 .13)\end{array}$ & 14.7 & 6.5 & & \\
\hline & II & $\begin{array}{l}55 \text { Middle of } \\
\text { heading: half of } \\
\text { inflorescence } \\
\text { emerged (11.05.12) } \\
59 \text { End of heading: } \\
\text { inflorescence fully } \\
\text { emerged }\end{array}$ & 12.0 & 48.6 & $\begin{array}{l}45 \text { Late boot stage: flag } \\
\text { leaf sheath swollen } \\
\text { (14.05.13) } \\
51 \text { Beginning of heading: } \\
\text { tip of inflorescence } \\
\text { emerged from sheath, } \\
\text { first spikelet just visible } \\
\text { (15.05.13) } \\
55 \text { Middle of heading: half } \\
\text { of inflorescence emerged } \\
59 \text { End of heading: } \\
\text { inflorescence fully } \\
\text { emerged (20.05.13) }\end{array}$ & 15.8 & 20.5 & & \\
\hline & III & $\begin{array}{l}61 \text { Beginning of } \\
\text { flowering: first } \\
\text { anthers visible } \\
65 \text { Full flowering: } \\
50 \% \text { of anthers } \\
\text { mature (28.05.12) }\end{array}$ & 14.8 & 2.3 & $\begin{array}{c}61 \text { Beginning of } \\
\text { flowering: first anthers } \\
\text { visible }\end{array}$ & 13.8 & 27.5 & & \\
\hline & $\mathrm{x} / \sum$ & & 13.4 & 51.7 & & 14.8 & 54.5 & 13.5 & 58.5 \\
\hline \multirow{4}{*}{ June } & I & $\begin{array}{l}69 \text { End of flowering: } \\
\text { all spikelets have } \\
\text { completed flowering } \\
\text { but some dehydrated } \\
\text { anthers may remain }\end{array}$ & 12.2 & 33.8 & $\begin{array}{l}65 \text { Full flowering: } 50 \% \text { of } \\
\text { anthers mature }(03.06 .13)\end{array}$ & 16.3 & 26.4 & & \\
\hline & II & $\begin{array}{l}71 \text { Watery ripe: first } \\
\text { grains have reached } \\
\text { half their final size }\end{array}$ & 16.5 & 18.5 & $\begin{array}{c}69 \text { End of flowering: all } \\
\text { spikelets have completed } \\
\text { flowering }\end{array}$ & 18.2 & 0 & & \\
\hline & III & Early milk & 16.4 & 50.9 & $\begin{array}{l}71 \text { Watery ripe: first grains } \\
\text { have reached half their } \\
\text { final size } \\
73 \text { Early milk }\end{array}$ & 18.1 & 34.8 & & \\
\hline & $\mathrm{x} / \sum$ & & 15.0 & 103.2 & & 17.5 & 61.2 & 16.1 & 80.4 \\
\hline \multirow{4}{*}{ July } & $\mathrm{I}$ & 83 Early dough & 21.6 & 76.7 & 83 Early dough & 18.2 & 16.9 & & \\
\hline & II & $\begin{array}{l}87 \text { Hard dough: } \\
\text { grain content } \\
\text { solid. Fingernail } \\
\text { impression held } \\
\end{array}$ & 15.5 & 32.1 & $\begin{array}{l}87 \text { Hard dough: grain } \\
\text { content solid. Fingernail } \\
\text { impression held }\end{array}$ & 16.6 & 100.9 & & \\
\hline & III & $\begin{array}{l}91 \text { Over-ripe: grain } \\
\text { very hard, cannot be } \\
\text { dented by thumbnail } \\
\text { - harvest (31.07.12) }\end{array}$ & 19.9 & 12.2 & $\begin{array}{c}91 \text { Over-ripe: grain very } \\
\text { hard, cannot be dented } \\
\text { by thumbnail - harvest } \\
(31.07 .12)\end{array}$ & 19.1 & 4.1 & & \\
\hline & $\mathrm{x} / \sum$ & & 19.0 & 121.0 & & 18.0 & 121.9 & 18.7 & 74.2 \\
\hline
\end{tabular}

30 Beginning of stem

elongation: pseudostem

and tillers erect, firs

internode begin

to elongate, top of

forescence at least

(06.05.13)

2 Node 2 at least $2 \mathrm{~cm}$

14.05.13)

Beginning of heading

tip of inflorescence

merged from sheath,

kelet just visible $\quad 15.8 \quad 20.5$

Middle of heading: hal

inflorescence emerge

59 End of heading:

inflorescence fully

erged $(20.05 .13)$

61 Beginning o 


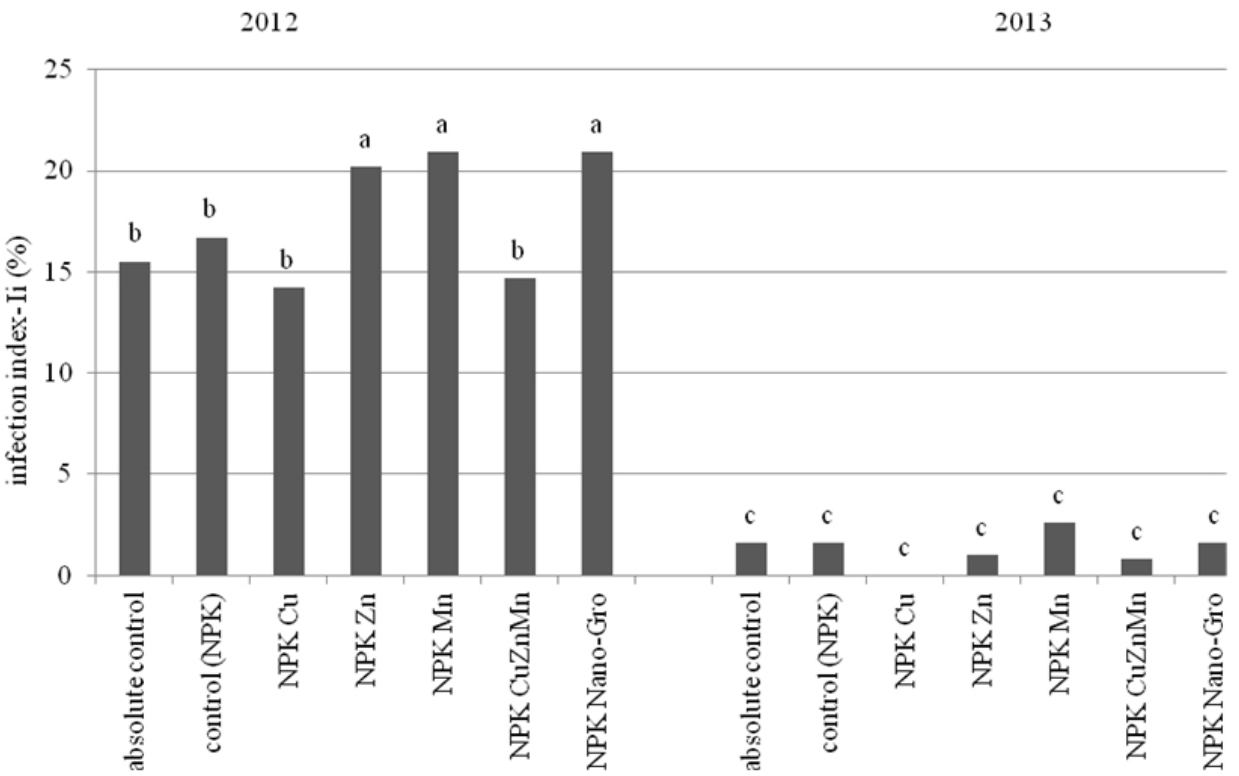

Figure 1 Severity of Fusarium head blight in winter rye; Ii -infestation index (\%)

of $\mathrm{N}$ fertiliser may affect soil $\mathrm{pH}$ and the availability of other nutrients, e.g. manganese (44). High rates of $\mathrm{N}$ fertilisation in the form of $\mathrm{NH}_{4}$ inhibit the growth of $F$. graminearum (Gibberella zeae). Yang et al. (45) and Liew et al. (46) reported that $\mathrm{Cu}$ and $\mathrm{B}$ applied to the leaves limited the development of the cereal diseases they studied and enabled high yields without the use of chemical crop protection agents.

\section{Fusarium spp. and fusariotoxins}

Ergosterol (ERG), a sterol found in the cell membranes of fungi, spores, and vegetative cells of filamentous fungi, is an indicator of the presence of fungi in cereal grains (34, 47). In our study, the 2013 ERG concentrations were high in rye grain samples collected from all but the $\mathrm{NPK}+\mathrm{Cu}$ treatment (Figure 2). In 2012, ERG levels were lower and similar in all samples collected from plants treated with foliar micronutrients. In agricultural research that the top acceptable limit for ERG level is $7.0 \mu \mathrm{g} \mathrm{g}^{-1}$ (48). Ergosterol content is an indicator of the total content of the fungal biomass, including toxigenic and non-toxigenic fungi. This is why high ERG levels do not necessarily correlate with mycotoxin levels, especially in plant samples naturally contaminated with mycotoxins (49). The correlation between ERG and mycotoxins levels, however, was reported in controlled experiments with inoculation with Fusarium pathogens (50).

2012

2013

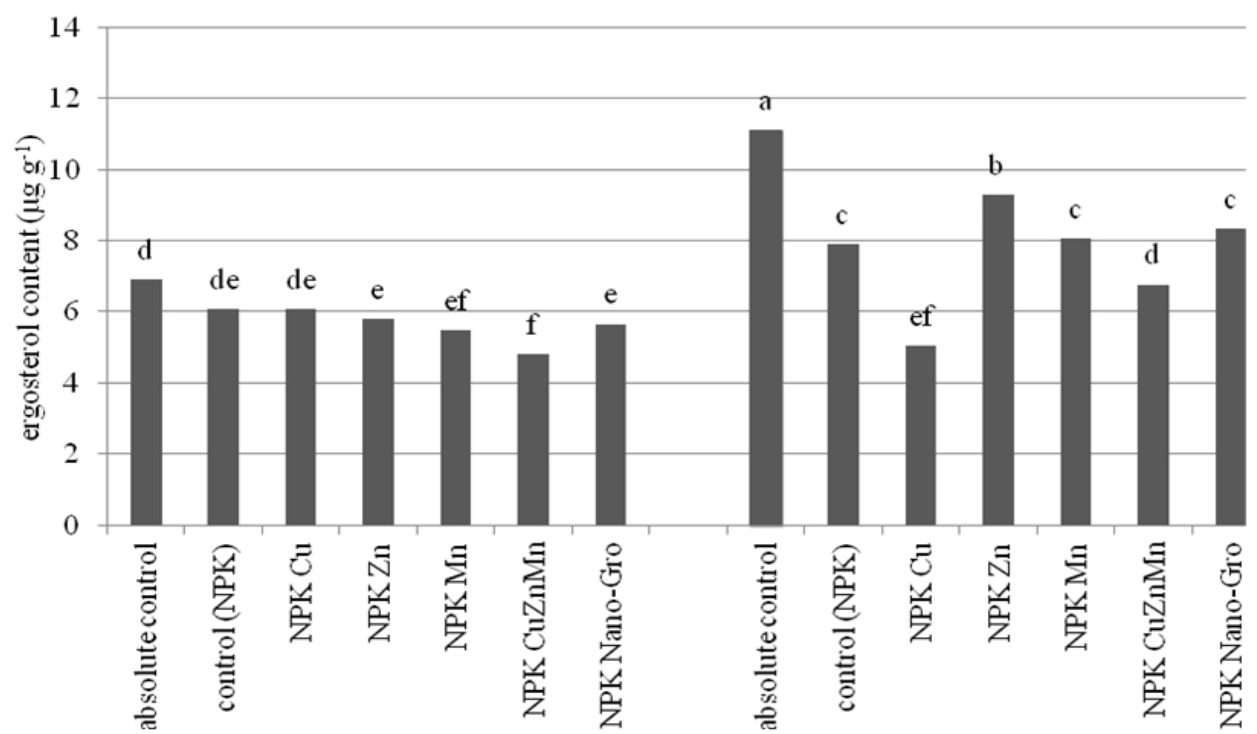

Figure 2 Ergosterol levels $\left(\mu g g^{-1}\right)$ in winter rye samples 


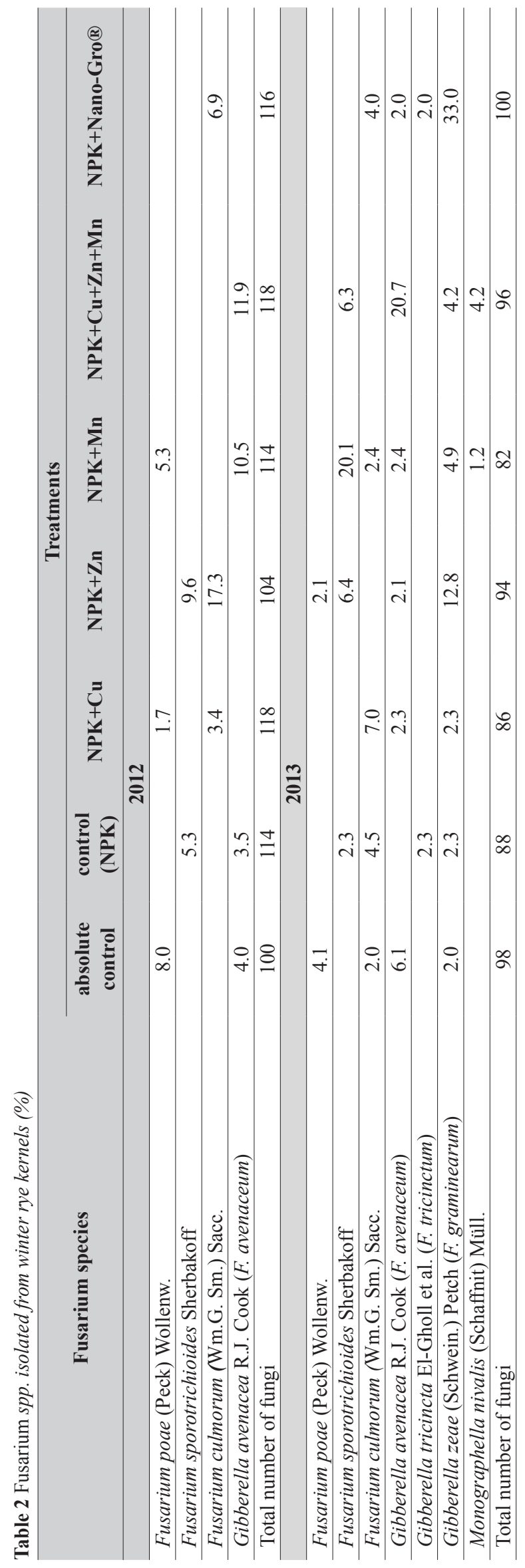

The most common Fusarium mycotoxins in cereal grains are type B trichothecenes (DON and NIV), ZEA, and MON (2-3). Numerous authors (51-52) reported the presence of mycotoxins, DON in particular, in all types of cereal grains grown in 226 regions of the world. According to Sadowski et al. (53), DON is the most common mycotoxin that contaminates grain in Poland. Increased levels of DON in cereal grains (51) are observed in years with heavy rainfall and high humidity in the flowering stage, which results in high FHB severity. In our study, high DON levels (above the allowed limits) in the rye harvested in 2012 were consistent with our FHB severity findings (Figure 3). Its concentrations were the lowest in grain treated with NPK alone, and NPK plus $\mathrm{Cu}$. These two treatments and the treatment with NPK plus Nano-Gro ${ }^{\circledR}$ showed the lowest levels of toxin-producing Fusarium species, F. avenaceum, F. culmorum, F. poae and $F$. sporotrichioides $(8.8 \%, 5.1 \%$, and $6.9 \%$, respectively).

In plants receiving other treatment the mycotoxin concentrations were significantly higher and the colonies of Fusarium spp. much more abundant. Fusarium culmorum was the most common species in the NPK $+\mathrm{Zn}$ treatment, and F. culmorum and F. sporotrichioides accounted for about $27 \%$ of all isolates (Table 2). Buttner (52) found the above species in $50 \%$ of the 80 tested samples of rye grain; $43 \%$ samples were infected by F. graminearum. Polish and German authors $(4,53)$ have pointed to a relationship between FHB severity and DON content, which is consistent with our findings, and is quite expected, considering that F. culmorum is the main producer of DON.

Our findings for 2013 revealed low levels of DON contamination, ranging from $100 \mathrm{ng} \mathrm{g}^{-1}(\mathrm{NPK}+\mathrm{Cu}+\mathrm{Zn}+\mathrm{Mn}$, NPK+Nano-Gro ${ }^{\circledR}$ ) to $910 \mathrm{ng} \mathrm{g}^{-1}$ (control without fertiliser treatment). Yet fungal colonisation of the rye kernels was higher in 2013 than in 2012, particularly in the NPK $+\mathrm{Mn}$, $\mathrm{NPK}+\mathrm{Cu}+\mathrm{Zn}+\mathrm{Mn}$, and $\mathrm{NPK}+\mathrm{Nano}-\mathrm{Gro}^{\circledR}$ treatments, what no correlation with mycotoxin levels - higher concentrations of mycotoxins were in rye samples in 2012. Twarużek et al. (54) also reported that even though the Fusarium fungi had a high share of the total fungal biomass, the production of secondary fungal metabolites in rye grain was insignificant, and DON was detected only in individual samples. In our study DON was detected in the grain from all treatments in both study years, but its producer $F$. graminearum was not isolated in the first year, and $F$. culmorum was not isolated in either year. This situation is normal for field experiments; there are plant samples contaminated with mycotoxins which do not have any Fusarium spp. or FHB symptoms and, vice versa, there are plant samples contaminated with various toxigenic Fusarium spp. but not with mycotoxins.

Like DON, NNIV also showed significantly higher levels in 2012 than in 2013 (Figure 4). The highest NIV concentrations (800-835 $\mathrm{ng} \mathrm{g}^{-1}$ ) were noted in untreated (control) kernels and those treated with NPK+Nano-Gro ${ }^{\circledR}$, 
and the observed differences were significantly higher than in the rest of the treatments.

Similar to the trichothecenes, ZEA levels were higher in 2012 than in 2013 (Figure 5). The most contaminated kernels were harvested from plants treated with $\mathrm{NPK}+$ micronutrients, and significant differences in mycotoxin content were noted between the $\mathrm{NPK}+\mathrm{Cu}$ and $\mathrm{NPK}+\mathrm{Nano}-\mathrm{Gro}^{\circledR}$ treatments versus the rest of the treatments. In 2013, ZEA levels were below $10 \mathrm{ng} \mathrm{g}^{-1}$ and similarly distributed across the treatments.

The same is true for MON levels: significantly higher in 2012 than in 2013 (Figure 6). Treatment significantly reduced MON levels compared to untreated (absolute control) samples, and the most efficient were the NPK and the $\mathrm{NPK}+\mathrm{Cu}, \mathrm{Zn}, \mathrm{Mn}$ treatments in both 2012 and 2013

With FB1 the situation was different; its levels were equally low in both study years, ranging from $3.3 \mathrm{ng} \mathrm{g}^{-1}$ $(\mathrm{NPK}+\mathrm{Zn}+\mathrm{Cu}+\mathrm{Mn})$ to $17.4 \mathrm{ng} \mathrm{g}^{-1}(\mathrm{NPK}+\mathrm{Mn})$ in 2013 (Figure 7). In 2012, the most effective against FB1 was the $\mathrm{NPK}+\mathrm{Zn}+\mathrm{Cu}+\mathrm{Mn}$ treatment $\left(6.6 \mathrm{ng} \mathrm{g}^{-1}\right)$.

Fumonisin B2 was not detected in rye grain. Mycotoxins such as enniatins and beauvericin accumulate in smaller amounts in cereal grains than trichothecenes and ZEA (33, $55)$.

\section{Coefficients of correlation}

We found a positive correlation (Pearson's r) between Fusarium head blight FHB and the concentrations of ZEA, MON, DON, and NIV in rye grain (Table 3 ). In the case of the latter two mycotoxins, the correlation coefficient was close to unity (0.931-0.932). According to Waśkiewicz et al. (9), Zhang et al. (56), and Ji et al. (57), mycotoxin content in grain positively correlates with the severity of FHB. By contrast, Lacey et al. (58) reported the presence of DON in grain with no macroscopic symptoms of FHB or grain colonisation by Fusarium spp. These controversial findings could result from differences in infection severity, different plant development stages, and different grain harvest methods (59-60).

Table 3 Correlation coefficients between Fusarium head blight and ergosterol and mycotoxin levels in winter rye grain

\begin{tabular}{ll}
\hline Compound & $\mathbf{r}$ \\
\hline Ergosterol & $-0.615^{*}$ \\
\hline Fumonisin B1 & 0.008 \\
\hline Zearalenone & $0.746^{*}$ \\
\hline Moniliformin & $0.884^{*}$ \\
\hline Deoxynivalenol & $0.931^{*}$ \\
\hline Nivalenol & $0.932 *$ \\
\hline correlation coefficients are significant at $\alpha<0.05 ; N=28$
\end{tabular}

\section{REFERENCES}

1. Miedaner T, Reinbrecht C, Lauber U, Schollenberger M, Geiger HH. Effects of genotype and genotype-environment interaction on deoxynivalenol accumulation and resistance to Fusarium head blight in rye, triticale, and wheat. Plant Breed 2001;120:97-105. doi: 10.1046/j.1439-0523.2001. 00580.x

2. Goliński P, Waśkiewicz A, Gromadzka K. Mycotoxins and mycotoxicoses under climatic conditions of Poland. Pol J Vet Sci 2009;12:581-8. PMID: 20169938.

3. Goliński P, Waśkiewicz A, Wiśniewska H, Kiecana I, Mielniczuk E, Gromadzka K, Kostecki M, Bocianowski J, Rymaniak E. Reaction of winter wheat (Triticum aestivum L.) cultivars to infection with Fusarium spp.: mycotoxin contamination in grain and chaff. Food Addit Contam Part A Chem Anal Control Expo Risk Assess 2010;27:1015-24. doi: 10.1080/19440041003702208

4. Solarska E, Kuzdraliński A, Potocka E. Mikotoksyny w życie ozimym uprawianym w ekologicznym systemie produkcji [Mycotoxins in winter rye cultivated in organic production system, in Polish]. J Res Appl Agric Engin 2010;55:108-22.

5. Schaafsma AW, Tamburic-Ilinic L, Miller JD, Hooker DC. Agronomic considerations for reducing deoxynivalenol in wheat grain. Can J Plant Pathol 2001;23:279-85. doi: 10.1080/07060660109506941

6. Langevin F, Eudes F, Comeau A. Effect of trichothecenes produced by Fusarium graminearum during Fusarium head blight development in six cereal species. Eur J Plant Pathol 2004;110:735-46. doi: 10.1023/B:EJPP.0000041568.31778. ad

7. Liddell CM. Systematics of Fusarium species and allies associated with Fusarium head blight. In: Leonard KJ, Bushnell WR, editors. Fusarium head blight of wheat and barley. St. Paul (MN): APS Press; 2003. p 35-43.

8. Pirgozliev SR, Edwards SG, Hare MC, Jenkinson P. Strategies for the control of Fusarium head blight in cereals. Eur J Plant Pathol 2003;109:731-42. doi: 10.1023/A:1026034509247

9. Waśkiewicz A, Gromadzka K, Wiśniewska H, Goliński P. Accumulation of zearalenone in genotypes of spring wheat after inoculation with Fusarium culmorum. Cereal Res Commun 2008;36(Suppl 6):401-4.

10. Waśkiewicz A, Wit M, Goliński P, Chełkowski J, Warzecha R, Ochodzki P, Wakuliński W. Kinetics of fumonisin B1 formation in maize ears inoculated with Fusarium verticillioides. Food Add Contam 2012;29:1752-61. doi: 10.1080/19440049.2012.712061

11. Bottalico A, Perrone G. Toxigenic Fusarium species and mycotoxins associated with head blight in small-grain cereals in Europe. Plant Pathol 2002;108:611-24. doi: 10.1023/A:1020635214971

12. Rintelen J. Zum Infektionszeitpunkt von Fusarien an Weizenkornern [To the time of infection by Fusarium in wheat grains, in German]. Gesunde Pflanz 1995;47:315-7.

13. Champeil A, Doré T, Fourbet JF. Fusarium head blight: epidemiological origin of the effect of cultural practices on head blight attacks and production of mycotoxins by Fusarium in whaet grains. Plant Sci 2004;166:1389-415. doi: 10.1016/j.plantsci.2004.02.004

14. Agrios NG. Plant Pathology. $5^{\text {th }}$ ed. London: ElsevierAcademic Press; 2005. 


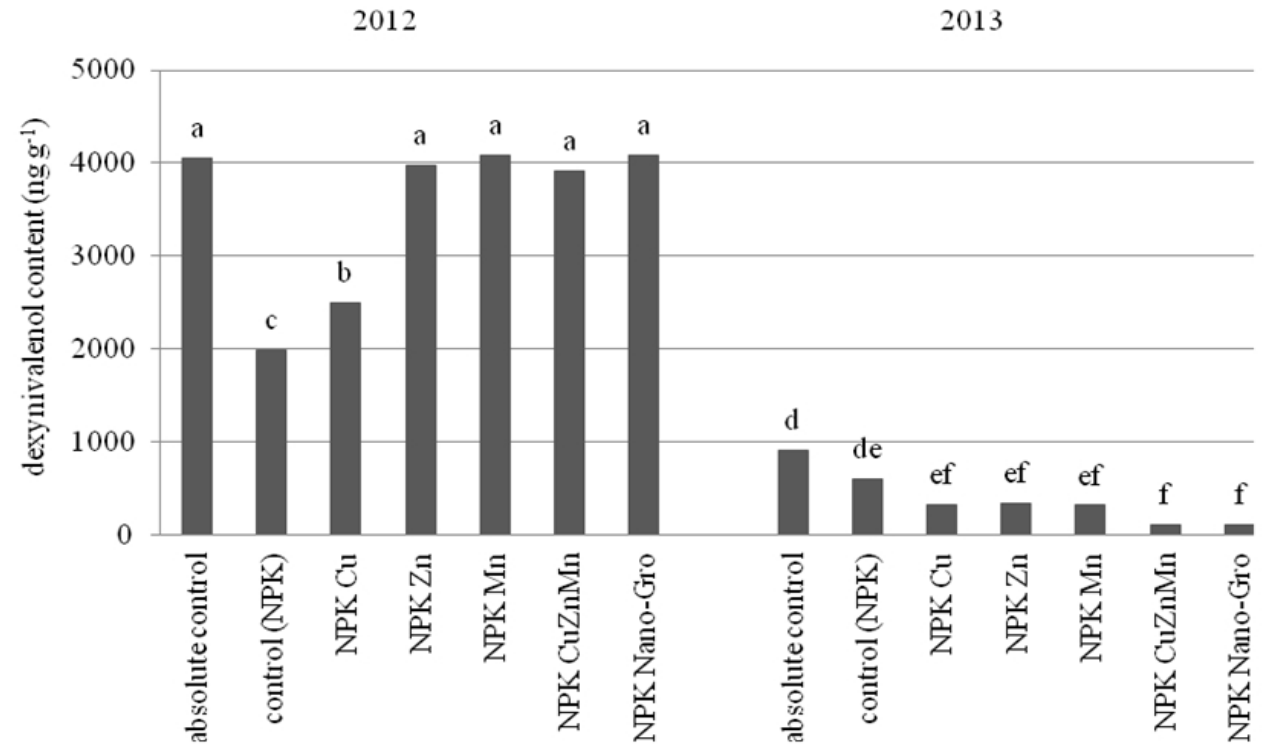

Figure 3 Deoxynivalenol levels $\left(n g g^{-1}\right)$ in winter rye samples

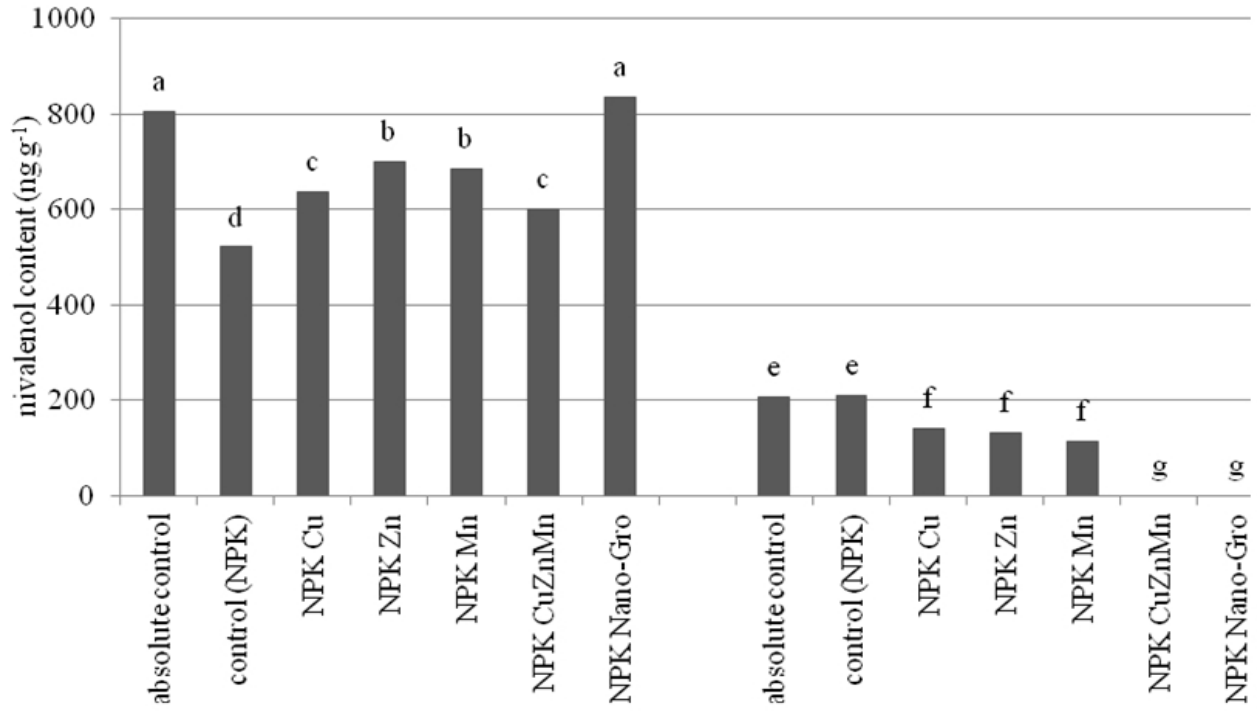

Figure 4 Nivalenol levels $\left(n g g^{-1}\right)$ in winter rye samples

15. Dordas C. Role of nutrients in controlling plant diseases in sustainable agriculture. A review. Agron Sustain Dev 2008;28:33-46. doi: 10.1051/agro:2007051

16. Hoffland E, Jegger MJ, van Beusichem ML. Effect of nitrogen supply rate on disease resistance in tomato depends on the pathogen. Plant Soil 2000;218:239-47. doi: 10.1023/A:1014960507981

17. Hammerschmidt R, Nicholson RL. A survey of plant defense responses to pathogens. In: Agrawal AA, Tuzun S, Bent E, editors. Induced plant defenses against pathogens and herbivores: biochemistry, ecology, and agriculture. St. Paul (MN): APS Press; 2000. p. 55-71.

18. Cakmak IM. Possible roles of zinc in protecting plant cells from damage by reactive oxygen species. New Phytol 2000;146:185-205. doi: 10.1046/j.1469-8137.2000.00630.x
19. Evans I, Solberg E, Huber DM. Copper and plant disease. In: Datnoff LE, Elmer WH, Huber DM, editors. Mineral nutrition and plant disease. St. Paul (MN): APS Press; 2007. p. $177-88$.

20. Stangoulis JCR, Graham RD. Boron and plant disease In: Datnoff LE, Elmer WH, Huber DM, editors. Mineral nutrition and plant disease. St. Paul (MN): APS Press; 2007. p. 207-14.

21. Hartikainen ES, Lankinen P, Rajasärkkä J, Koponen H, Virta M, Hatakka A, Kähkönen MA. Impact of copper and zinc on the growth of saprotrophic fungi and the production of extracellular enzymes. Boreal Environ Res 2012;17:210-8.

22. Savi GD, Bortoluzzi AJ, Scussel VM. Antifungal properties of zinc-compounds against toxigenic fungi and mycotoxin. Int J Food Sci Technol 2013;48:1834-40. doi: 10.1111/ ijfs. 12158 


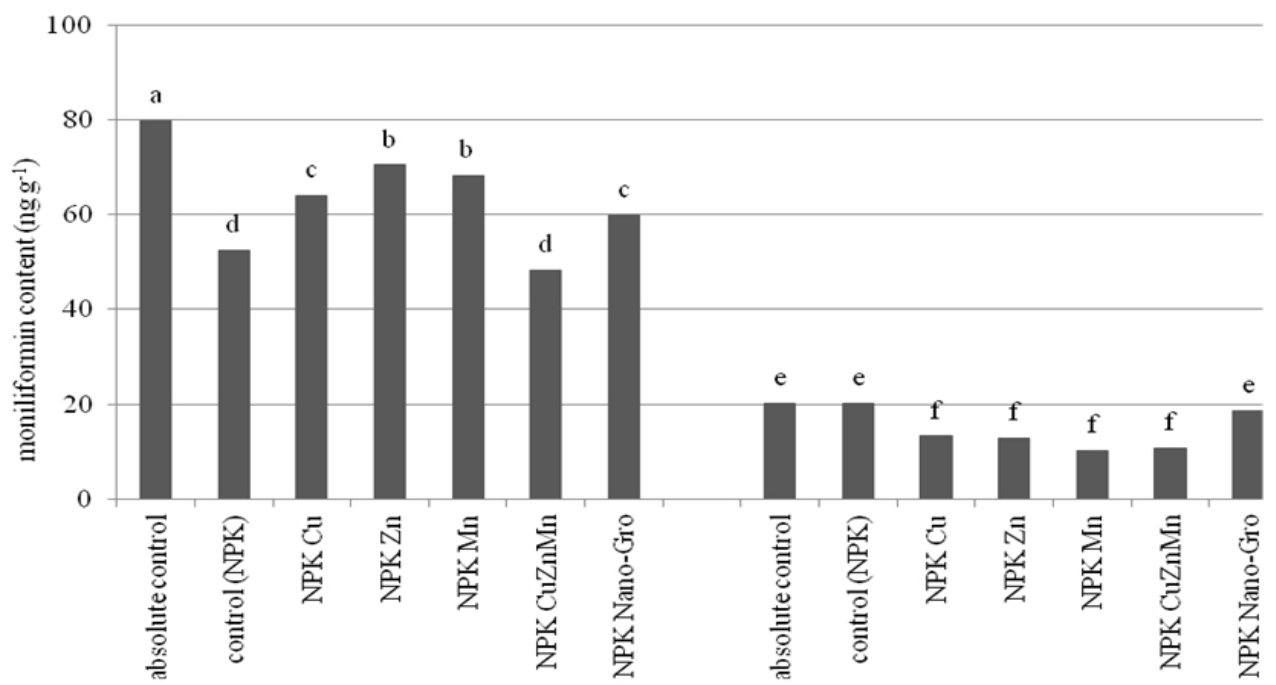

Figure 6 Moniliformin concentrations $\left(n g g^{-1}\right)$ in winter rye samples

2012

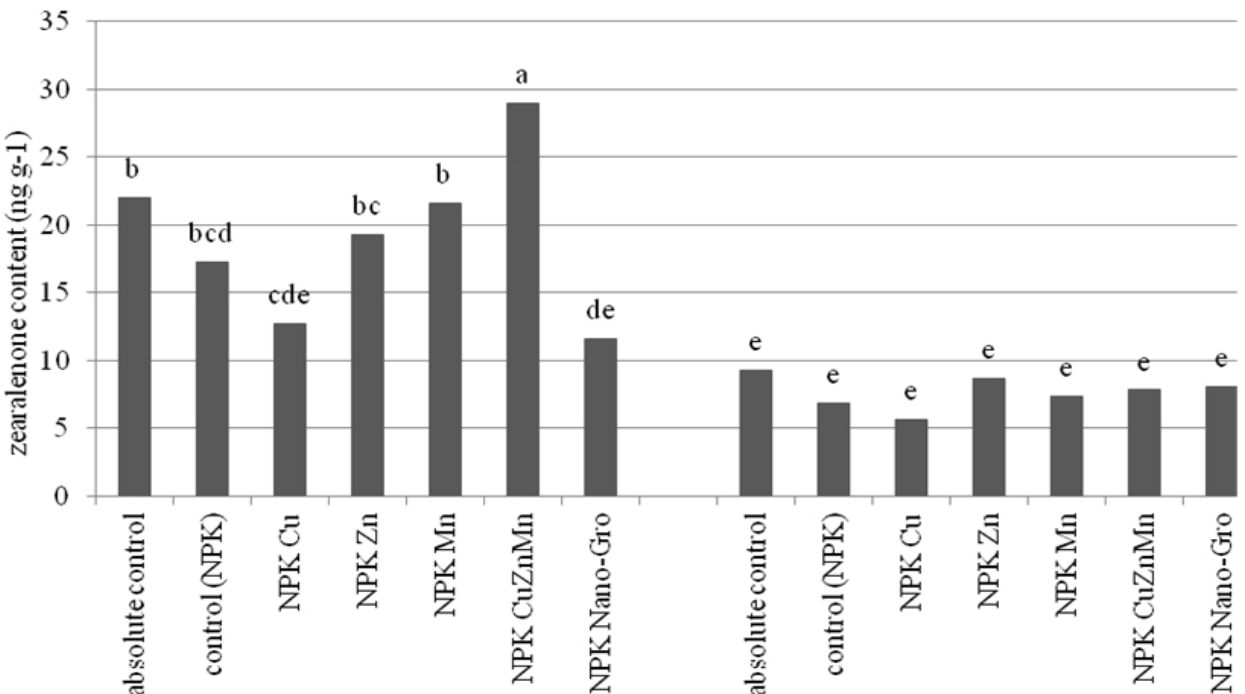

Figure 5 Zearalenone levels $\left(n g g^{-1}\right)$ in winter rye samples

23. Ivić D, Domijan A-M, Peraica M, Miličević T, Cvjetković B. Fusarium spp. contamination of wheat, maize, soybean, and pea in Croatia. Arh Hig Rada Toksikol 2009;60:435-42. doi: 10.2478/10004-1254-60-2009-1963

24. Nicholson P, Simpson DR, Wilson AH, Chandler E, Thomsett $M$. Detection and differentiation of trichothecene and enniatin-producing Fusarium species on small-grain cereals. Eur J Plant Pathol 2004;110:503-14. doi: 10.1023/B:EJPP.0000032390.65641.a7

25. Gräfenhan T, Patrick SK, Roscoe M, Trelka R, Gaba D, Chan JM, McKendry T, Clear RM, Tittlemier SA. Fusarium damage in cereal grains from Western Canada. 1. Phylogenetic analysis of moniliformin-producing Fusarium species and their natural occurrence in mycotoxin-contaminated wheat, oats, and rye. J Agric Food Chem 2013;61:5425-37. doi: $10.1021 / \mathrm{jf} 400651 \mathrm{p}$
26. Błajet-Kosicka A, Twarużek M, Kosicki R, Sibiorowska E, Grajewski J. Co-occurrence and evaluation of mycotoxins in organic and conventional rye grain and products. Food Control 2014;38:61-6. doi: 10.1016/j.foodcont.2013.10.003

27. Hussein HS, Brasel JM. Toxicity, metabolism, and impact of mycotoxins on humans and animals. Toxicology 2001;167:101-34. doi: 10.1016/S0300-483X(01)00471-1

28. Pestka JJ. Deoxynivalenol: Toxicity, mechanism and animals health risk. Anim Feed Sci Technol 2007;137:283-98. doi: 10.1016/j.anifeedsci.2007.06.006

29. Zinedine A, Soriano JM, Molto JC, Mañes J. Review on the toxicity, occurrence, metabolism, detoxification, regulations and intake of zearalenone: An oestrogenic mycotoxin. Food Chem Toxicol 2007;45:1-18. doi: 10.1016/j.fct.2006.07.030

30. Nicholson P, Chandler E, Draeger RC, Gosman NE, Simpson DR, Thomsett M, Wilson AH. Molecular tools to study 


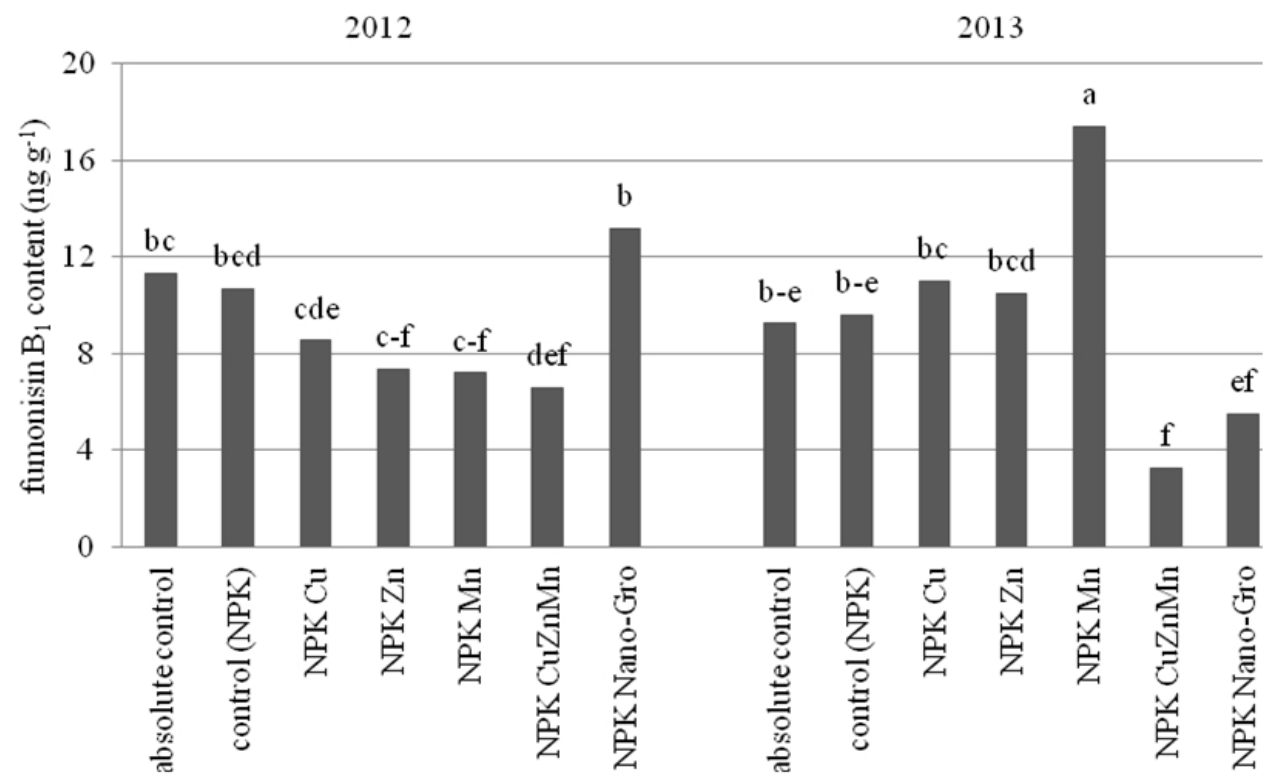

Figure 7 Fumonisin $B_{1}$ concentrations $\left(n g g^{-1}\right)$ in winter rye samples

epidemiology and toxicology of Fusarium head blight of cereals. Eur J Plant Pathol 2003;109:691-703. doi: 10.1023/A:1026026307430

31. Czembor E, Stępień Ł, Waśkiewicz A. Effect of environmental factors on Fusarium species and associated mycotoxins in maize grain grown in Poland. PLoS One 2015;10(7):e0133644. doi: 10.1371/journal.pone.0133644

32. Lacko-Bartošova M, Kobida L. Incidence of Fusarium mycotoxins and wheat yields in integrated and ecological systems. J Ecol Health 2011;15:19-23.

33. Waśkiewicz A, Stępień Ł. Mycotoxins biosynthesized by plant-derived Fusarium isolates. Arh Hig Rada Toksikol 2012;63:437-46. doi: 10.2478/10004-1254-63-2012-2230

34. Waśkiewicz A, Irzykowska L, Bocianowski J, Karolewski Z, Weber Z, Goliński P. Fusariotoxins in asparagus - their biosynthesis and migration. Food Add Contam 2013;30:13328. doi: 10.1080/19440049.2013.796095

35. Creppy EE. Update of survey, regulation and toxic effects of mycotoxins in Europe. Toxicol Lett 2002;127:19-28. doi: 10.1016/S0378-4274(01)00479-9

36. Fung F, Clark RF. Health effects of mycotoxins: A toxicological overview. J Toxicol Clinical Toxicol 2004:42:217-34. doi: 10.1081/CLT-120030947

37. Zain ME. Impact of mycotoxins on humans and animals. J Saudi Chem Soc 2011;15:129-44. doi: 10.1016/j.jscs.2010.06 006

38. Commission Regulation (EC) No 1126/2007 of 28 September 2007 amending Regulation (EC) No 1881/2006 setting maximum levels for certain contaminants in foodstuffs as regards Fusarium toxins in maize and maize products (Text with EEA relevance) [displayed 7 March 2017]. Available at http://eur-lex.europa.eu/legal-content/EN/ ALL/?uri=CELEX\%3A32007R1126

39. World reference base for soil resources. International soil classification system for naming soils and creating legends for soil maps. World Soil Resources Reports 2014;106. FAO, Rome.

40. Meier U. Growth stages of mono-and dicotyle- donous plants - BBCH Monograph. 2001.
41. Booth T.C. The genus Fusarium. Commonwealth Mycological Institute Kew Surrey, England, 1971;237.

42. Nelson P.E., Toussoun T.A., Marasas W.F.0. Fusarium species: an illustrated manual for identification. Pennsylvania State University Press, University Park 1983;328.

43. Čonkova E, Laciakova A, Štyriak I, Czerwiecki L, Wilczyńska G. Fungal contamination and the levels of mycotoxins (DON and OTA) in cereal samples from Poland and East Slovakia. J Food Sci 2006;24:33-40.

44. Celar F. Competition for ammonium and nitrate forms of nitrogen between some phytopathogenic and antagonistic soil fungi. Biol Control 2003;28:19-24. doi: 10.1016/S10499644(03)00049-5

45. Yang M, Shi L, Xu FS, Lu JW, Wang YH. Effects of B, Mo, $\mathrm{Zn}$ and their interactions on seed yield of (Brassica napus L.). Pedosphere 2009;19:53-9. doi: 10.1016/S10020160(08)60083-1

46. Liew YA, Syed Omar SR, Husni MHA, Zainal AMA, Nur Ashikin PA. Effects of foliar applied copper and boron on fungal diseases and rice yield on cultivar MR219. Pertanika J Trop Agric Sci 2012;35:339-49.

47. Miyagawa H, Umeda M, Sato T, Bandoh S, Nakamura S, Goto T. Single-laboratory validation of a method for ergosterol determination in cereals. Food Addit Contam Part A Chem Anal Control Expo Risk Assess 2009;26:201-6. doi: 10.1080/02652030802399018

48. Gutarowska B, Żakowska Z. Estimation of fungal contamination of various plant materials with UVdetermination of fungal ergosterol. Ann Microbiol 2010;60:415-22. doi: 10.1007/s13213-010-0057-9

49. Stanisz E, Zgoła-Grześkowiak A, Waśkiewicz A, Stępień $Ł$, Beszterda M. Can ergosterol be an indicator of Fusarium fungi and mycotoxins in cereal products? J Braz Chem Soc 2015;26:705-12. doi: 10.5935/0103-5053.20150030

50. Waśkiewicz A, Goliński P, Karolewski Z, Irzykowska L, Bocianowski J, Kostecki M, Weber Z. Formation of fumonisins and other secondary metabolites by Fusarium oxysporum and F. proliferatum: a comparative study. Food Add Contamin 2010;27: 608-15. 
51. Berg T, Ghorbani F, Rasmussen PH. Deoxynivalenol and other Fusarium toxins in wheat and rye flours on the Danish market. Food Add Contam 2003;20:396-404. doi: 10.1080/0265203031000082495

52. Buttner P. Das Artenspektrum der Gattung Fusarium an Weizen und Roggen in Bayern in des Jahren 2003 und 2004 [Species of Fusarium occuring in the years 2003 and 2004 on wheat and rye in Bavaria, in Germany]. Gesunde Pflanzen 2006;58:28-33. doi: 10.1007/s10343-005-0102-y

53. Sadowski C, Lenc L, Lemańczyk G, Pańka D. Występowanie fuzariozy kłosów pszenicy ozimej (Fusarium culmorum chemotyp DON) w zależności od programu ochrony [Occurrence of Fusarium head blight of winter wheat (Fusarium culmorum - chemotype) in dependence on fungicidal protection programs, in Polish]. Prog Plant Prot/ Post Ochr Rośl 2009;49:1344-8.

54. Twarużek M, Grajewska-Wanat N, Błajet-Kosicka A, Grajewski J. Występowanie grzybów rodzaju Fusarium oraz głównych mikotoksyn w ziarnie zbóż w latach 2011-2012 [Occurrence of Fusarium and major mycotoxins in cereal grains harvested in 2011-2012, in Polish]. Prog Plant Prot./ Post Ochr Rośl 2013;53:801-6.

55. Magan N, Hope R, Colleate A, Baxter ES. Relationship between growth and mycotoxin production by Fusarium species, biocides and environment. Eur J Plant Pathol 2002;108:685-90. doi: 10.1023/A:1020618728175

56. Zhang JB, Wang JH, Gong AD, Chen FF, Song B, Li X, Li $\mathrm{HP}$, Peng $\mathrm{CH}$, Liao YC. Natural occurrence of fusarium head blight, mycotoxins and mycotoxin-producing isolates of Fusarium in commercial fields of wheat in Hubei. Plant Pathol 2013;62:92-102. doi: 10.1111/j.1365-3059.2012. 02639.x

57. Ji F, Wu J, Zhao H, Xu J, Shi J. Relationship of deoxynivalenol content in grain, chaff, and straw with Fusarium head blight severity in wheat varieties with various levels of resistance. Toxins (Basel) 2015;7:728-42. doi: 10.3390/toxins7030728

58. Lacey J, Bateman GL, Mirocha CJ. Effects of infection time and moisture on development of ear blight and deoxynivalenol production by Fusarium spp. in wheat. Ann Appl Biol 1999;134:277-83. doi: 10.1111/j.1744-7348.1999.tb05265.x

59. Bai GH, Plattner RD, Desjardins AE, Kolb FL. Resistance to Fusarium head blight and deoxynivalenol accumulation in wheat. Plant Breed 2001;120:1-6. doi: 10.1046/j.1439-0523. 2001.00562.x

60. Landschoot S, Waegeman W, Audenaert K, Vandepitte J, Baetens JM, De Baets B, Haesaert G. An empirical analysis of explanatory variables affecting Fusarium head blight infection and deoxynivalenol content in wheat. J Plant Pathol 2012;45:1-18. doi: 10.4454/jpp.fa.2012.021

\section{Djelovanje tretmana gnojivom na intenzitet fuzarijske paleži klasa i sintezu mikotoksina u zimskoj raži}

Gljivice iz roda Fusarium uzrokuju fuzarijsku palež klasa, bolest žitarica koja uništava urod i kakvoću zrna. Osim toga, ove gljivice proizvode mikotoksine koji mogu ozbiljno ugroziti zdravlje ljudi i životinja. Istražili smo djelovanje NPK gnojiva, organskoga stimulatora rasta Nano-Gro ${ }^{\circledR}$ te lisne primjene $\mathrm{Cu}, \mathrm{Zn}$ i Mn, zasebno ili u kombinaciji, na učestalost fuzarijske paleži klasa u zimskoj raži (kultivar Dańkowskie Diament) na temelju mikološke analize zrnja i koncentracije fuzarijskih mikotoksina u njima. Na intenzitet bolesti zrnja koju uzrokuje sedam vrsta Fusarium gljivica ponajviše su utjecale vremenske prilike $\mathrm{u}$ analiziranim razdobljima. Primijenjena gnojiva i organski stimulator rasta Nano-Gro ${ }^{\circledR}$ iskazali su različite učinke na razvoj fuzarijske paleži klasa i biosintezu fuzarijskih mikotoksina (deoksinivalenola, nivalenola, zearalenona i fumonizina) u zrnju. U 2013. najveći je pad zabilježen u razinama deoksinivalenola i nivalenola, dok su razine moniliformina bile niže u tretiranim nego u netretiranim uzorcima (apsolutna kontrola) u obje godine istraživanja. Intenzitet fuzarijske paleži klasa korelirao je s koncentracijama zearalenona, deoksinivalenola, nivalenola i moniliformina u uzorcima zrnja. Do izrazitijeg nakupljanja ergosterola došlo je u raži iz žetve 2013. u odnosu na 2012. godinu, a tretman gnojivom dodatno je povisio razine ergosterola u odnosu na kontrolu.

KLJUČNE RIJEČI: deoksinivalenol; ergosterol; gnojenje mikroelementima; FHB; fumonizini; gljivice; moniliformin; nivalenol; zearalenon 